\title{
Meningkatkan Pemahaman Belajar Siswa Pada Pembelajaran IPS Melalui Metode Simulasi Di Kelas VI SDN No.89 Sipatana
}

\author{
Suharti K. Mohamad \\ Sdn No.89 Sipatana \\ Mohamadsuharti@gmail.com
}

Received: 13 August 2021; Revised: 02 October 2021; Accepted: 14 December 2021

DOI: http://dx.doi.org/10.37905/aksara.8.1.483-490.2022

\begin{abstract}
Abstrak
Adapun yang menjadi tujuan dari pelaksanaan penelitian tindakan kelas ini adalah untuk meningkatkan pemahaman belajar siswa melalui metode simulasi di Kelas VI SDN No.89 Sipatana. Metode yang dipakai dalam penelitian tindakan kelas. penelitian ini dilaksanakan dalam bentuk siklus yang terdiri dari 4 tahap yaitu, Tahap Persiapan, Tahap Pelaksanaan tindakan, Tahap Pemantauan dan evaluasi, Tahap Analisis dan refleksi.

Berdasarkan hasil analisis dari dua siklus dan pembahasan, maka dapat disimpulkan bahwa hasil penelitian menunjukkan setiap kali tindakan dilakukan selalu mengalami peningkatan yang signifikan terbukti indikator kinerja yang ditetapkan berhasil yaitu jika sebelumnya jumlah siswa yang paham materi perjuangan melawan penjajah pada siklus 1 hanya sebanyak 9 siswa (69.23\%) meningkat pada siklus 2 menjadi 12 orang siswa (92.3\%) siswa. Sedangkan 1 atau $(7.69 \%)$ siswa merupakan jumlah siswa yang kurang paham dan akan diperbaiki melalui proses remedial.

Hasil tersebut memberikan gambaran perbedaan ketika guru kelas menggunakan proses pembelajaran yang konvensional tanpa memahami bagaimana kondisi siswa dalam mengikuti proses pembelajaran dengan pemilihan dan penerapan metode simulasi secara tepat dengan langkah-langkah yang sesuai disetiap tindakan memperoleh hasil pembelajaran yang maksimal. Oleh karenanya peneliti telah yakin bahwa dengan menggunakan Metode Simulasi dalam pelajaran IPS maka pemahaman belajar siswa Kelas VI SDN No 89 Sipatana akan meningkat dapat diterima.
\end{abstract}

Kata Kunci: Pemahaman Belajar, Metode Simulasi.

\section{PENDAHULUAN}

Mata pelajaran Ilmu Pengetahuan Sosial (IPS) di Sekolah Dasar merupakan salah satu mata pelajaran yang harus dipelajari siswa. Karenanya akan terjadi kecenderungan sikap dalam diri siswa terhadap mata pelajaran tersebut, baik yang positif maupun yang negatif. Siswa yang mempunyai sikap positif terhadap pelajaran IPS cendrung akan menempuh usahanya belajar dengan keras, mempunyai intensitas belajar yang tinggi, dan penuh konsentrasi terhadap pembelajaran IPS. Sebaliknya siswa yang bersikap negatif terhadap pelajaran IPS cenderung tidak akan menunjukkan kesungguhan dalam belajar. Oleh karena itu, salah satu faktor penting dalam keberhasilan pembelajaran IPS di SD adalah bergantung pada sumber daya siswa yang berproses dalam pembelajaran. Artinya penguasaan IPS tergantung dari tingkat hasil belajar siswa yang menerimanya.

Dalam mengajarkan materi tentano nerjuangan melawan penjajah pada mata pelajaran IPS, tentunya perjuangan 1 nbarkan oleh guru secara jelas, belum lagi anak usia Kelas VI Sekolah Dasar masih dalam tahap perkembangan dalam meningkatkan pemahaman belajar sehingga dibutuhkan keuletan oleh guru dalam menyampaikan materi pelajaran.

Terkadang guru sering menemui kesulitan dalam menjelaskan materi perjuangan melawan penjajah, karena siswa tidak dapat mengamati langsung terhadap materi yang diajarkan, sehingga intensitas dan keterlibatan siswa menjadi pasif, dimana siswa tidak 
perhatian, tidak bergairah, dan tidak antusias dalam mengikuti pelajaran. Kondisi yang demikian menyebabkan siswa sulit dalam meningkatkan hasil belajar.

Untuk menjawab kesulitan guru ini, perlu dicarikan solusi apa yang harus dilakukan agar siswa termotivasi untuk mempelajarinya, sehingga mampu meningkatkan pemahaman belajar di sekolah.

Berdasarkan data hasil observasi awal tentang pemahaman belajar siswa kelas VI di SDN No 89 Sipatana terhadap materi perjuangan melawan penjajah pada mata pelajaran IPS dengan menggunakan hasil pengamatan awal kegiatan siswa, diperoleh hasil analisis data bahwa dari 13 orang siswa yang terdiri dari 8 orang siswa laki-laki dan 5 orang siswa perempuan, diperoleh data hanya 5 orang siswa $(38.46 \%)$ yang paham dalam menjelaskan materi perjuangan melawan penjajah, sedangkan 8 orang siswa lainnya $(61.53 \%)$ belum paham dalam menjelaskan perjuangan melawan penjajah.

Penyebab rendahnya pemahaman belajar siswa diantaranya adalah proses pembelajaran yang belum optimal. Hal ini terlihat dari sikap pasif siswa, pembelajaran yang monoton, guru kurang kreatif, proses pembelajaran belum efektif dan guru mendominasi proses. Oleh sebab itu dalam proses pembelajaran guru harus dapat menciptakan suasana yang dapat memotivasi siswa untuk lebih aktif dengan menggunakan metode pembelajaran sehingga suasana belajar lebih menarik dan akhirnya dapat meningkatkan hasil belajar siswa.

Metode mengajar simulasi banyak digunakan pada pembelajaran IPS. Pembinaan kemampuan bekerjasama, komunikasi dan interaksi merupakan bagian dari keterampilan yang akan dihasilkan melalui pembelajarn simulasi. Metode mengajar simulasi lebih banyak menuntut aktivitas siswa sehingga metode simulasi sebagai metode yang berlandaskan pada pendekatan CBSA dan keterampilan proses.

Disamping itu, metode ini dapat digunakan dalam pembelajaran berbasis konstektual, salah satu contoh bahan pembelajaran dapat diangkat dari kehidupan sosial, nilai-nilai sosial maupun permasalahan-permasalahan sosial yang aktual maupun masa lalu untuk masa yang akan datang. Permasalahan- permasalahan yang berkaitan dengan nilai-nilai kehidupan sosial maupun membentuk sikap atau perilaku dapat dilakukan melalui pembelajaran ini.

Langsung maupun tidak langsung melalui simulasi pemahaman siswa yang berkaitan dengan materi perjuangan melawan penjajah dapat dikembangkan. Siswa akan menguasai konsep dan keterampilan intelektual, sosial, dan motorik dalam bidang-bidang yang dipelajarinya serta mampu belajar melalui situasi tiruan dengan sistem umpan balik dan penyempurnaan yang berkelanjutan yang berkenaan dengan materi perjuangan melawan penjajah.

Oleh karena itu permasalahan penelitian ini difokuskan pada sebuah penelitian tindakan kelas yang berjudul: "Meningkatkan Pemahaman Belajar Siswa Melalui Metode Simulasi di Kelas VI SDN No 89 Sipatana"

Adapun yang menjadi tujuan dari pelaksanaan penelitian tindakan kelas ini adalah untuk meningkatkan pemahaman belajar siswa melalui metode simulasi di Kelas VI SDN No 89 Sipatana

Pemahaman atau comprehension dapat diartikan menguasai sesuatu dengan pikiran. Karena itu belajar berati harus mengerti secara mental makna dan filosofisnya, maksud dari implikasinya serta aplikasi-aplikasinya, sehingga menyebabkan siswa dapat mernahami suatu situasi. Hal ini sangat penting bagi siswa yang belajar. 
Menurut Sardiman (2007:42) memahami maksudnya, menangkap maknanya, adalah tujuan akhir dari setiap belajar. Pemahaman memiliki arti yang sangat mendasar yang meletakkan bagian-bagian belajar pada proporsinya. Tanpa itu menurutnya skill, pengetahuan clan sikap tidak akan bermakna.

Lebih lanjut menurut Sardiman, pemahaman itu tidak dapat dipisahkan dari unsurunsur psikologis yang lain. Dengan motivasi, konsentrasi dan reaksi, subjek belajar dapat mengembangkan fakta-fakta, ide-ide atau skill. Ia mengingatkan bahwa pemahaman tidak sekadar tahu, tetapi juga menghendaki agar subjek belajar dapat memanfaatkan bahanbahan yang telah dipahami. Kalau sudah demikian, belajar akan bersifat mendasar.

Pemahaman yang dicapai oleh siswa dalam pembelajaran sangat erat kaitannya dengan rumusan tujuan intruksional yang direncanakan guru sebelumnya. Hal ini dipengaruhi pula oleh kemampuan guru sebagai perancang (designer) belajar mengajar.

Klasifikasi tujuan tersebut memungkinkan pemahaman siswa yang diperoleh dari kegiatan belajar-mengajar. Hal ini didasari oleh asumsi bahwa pemahaman siswa dapat dilihat dari hasil belajar dan tingkah laku siswa, sehingga hal ini memberikan pula petunjuk bagi guru dalam menentukan tujuan-tujuan pembelajaran dalam bentuk pemahaman yang diharapkan dari dalam diri siswa.

Uzer (2005:35) mengkasifikasikan tujuan pembelajaran kaitannya dengan taksonomi tingkat pemahaman siswa sebagai berikut:

Domain tujuan kognitif terdiri atas enam bagian yaitu: (1) kemampuan mengenal dan mengingat materi yang sudah dipelajari; (2) kemampuan memahami makna materi; (3) kemampuan menggunakan atau menerapkan materi yang sudah dipelajari; (4) kemampuan menguraikan materi dan mampu memahami hubungan diantara bagian yang satu dengan yang lain; (5) kemampuan memadukan konsep; (6) kemampuan memberikan pertimbangan terhadap nilai-nilai materi untuk tujuan tertentu.

Domain tujuan afektif terbagi dalam: (1) kemampuan memperhatikan dan memberikan respon, (2) sikap dan apresiasi seperti : menerima, menolak, atau tidak menghiraukan terhadap apa yang dipelajari, (3) penyatuan nilai, (4) mengacu pada karakter dan pribadi siswa.

Domain tujuan psikomotor terbagi dalam: (1) memberi respon serupa dengan yang diamati, (2) siswa menampilkan sesuatu menurut petunjuk-petunjuk, (3) responsrespons lebih terkoreksi dan kesalahan-kesalahan dibatasi sampai pada tingkat minimum, (4) mengartikulasi suatu rangkaian gerakan dengan membuat urutan yang tepat sesuai dengan yang diharapkan, dan (5) pngalamiahan, menuntut tingkah laku yang ditampilkan.

Dari uraian tersebut, dapat dikatakan bahwa yang dimaksud dengan pemahaman siswa dalam pembelajaran disini adalah mengacu pada kemampuan memahami makna materi yang dipelajari melalui kegiatan proses belajar mengajar, khususnya dalam pembelajaran IPS.

Metode simulasi merupakan salah satu metode mengajar yang dapat digunakan dalam pembelajaran kelompok. Proses pembelajaran yang menggunakan simulasi cenderung objeknya bukan benda atau kegiatan yang sebenarnya, melainkan kegiatan mengajar yang bersifat pura-pura. Kegiatan simulasi dapat dilakukan oleh siswa pada kelas tinggi di Sekolah Dasar. Dalam pembelajaran, siswa akan dibina kemampuannya berkaitan dengan keterampilan berinteraksi dan berkomunikasi dalam kelompok. Disamping itu, dalam metode simulasi siswa diajak untuk bermain peran beberapa perilaku yang dianggap sesuai dengan tujuan pembelajaran. 
Menurut Sa'ud (2005: 129) simulasi adalah sebuah replikasi atau visualisasi dari perilaku sebuah sistem, misalnya sebuah perencanaan pendidikan, yang berjalan pada kurun waktu yang tertentu. Jadi dapat dikatakan bahwa simulasi itu adalah sebuah model yang berisi seperangkat variabel yang menampilkan ciri utama dari sistem kehidupan yang sebenarnya. Simulasi memungkinkan keputusan-keputusan yang menentukan bagaimana ciri-ciri utama itu bisa dimodifikasi secara nyata.

Sedangkan menurut Pusat Bahasa Depdiknas (2005) simulasi adalah satu metode pelatihan yang memperagakan sesuatu dalam bentuk tiruan (imakan) yang mirip dengan keadaan yang sesungguhnya; simulasi: penggambaran suatu sistem atau proses dengan peragaan memakai model statistic atau pemeran.

Anitah, W. Dkk (2007: 5.22) metode simulasi merupakan salah satu metode pembelajaran yang dapat digunakan dalam pembelajaran kelompok. Proses pembelajaran yang menggunakan metode simulasi cenderung objeknya bukan benda atau kegiatan yang sebenarnya, melainkan kegiatan mengajar yang bersifat pura-pura. Kegiatan simulasi dapat dilakukan oleh siswa pada kelas tinggi di sekolah dasar.

Dalam pembelajaran yang menggunakan metode simulasi, siswa dibina kemampuannya berkaitan dengan keterampilan berinteraksi dan berkomunikasi dalam kelompok. Di samping itu, dalam metode simulasi siswa diajak untuk dapat bermain peran beberapa perilaku yang dianggap sesuai dengan tujuan pembelajaran.

Metode mengajar simulasi banyak digunakan pada pembelajaran IPS, PKn, Pendidikan Agama, dan Pendidikan Apresiasi. Pembinaan kemampuan bekerjasama, komunikasi dan interaksi merupakan bagian dari keterampilan yang akan dihasilkan melalui pembelajarn simulasi.

Disamping itu, metode ini dapat digunakan dalam pembelajaran berbasis konstektual, salah satu contoh bahan pembelajaran dapat diangkat dari kehidupan sosial, nilai-nilai sosial maupun permasalahan-permasalahan sosial yang aktual maupun masa lalu untuk masa yang akan datang. Permasalahan- permasalahan yang berkaitan dengan nilai-nilai kehidupan sosial maupun membentuk sikap atau perilaku dapat dilakukan melalui pembelajaran ini.

Langsung maupun tidak langsung melalui simulasi kemampuan siswa yang berkaitan dengan bermain peran dapat dikembangkan. Siswa akan menguasai konsep dan keterampilan intelektual, sosial, dan motorik dalam bidang-bidang yang dipelajarinya serta mampu belajar melalui situasi tiruan dengan sistem umpan balik dan penyempurnaan yang berkelanjutan.

\section{METODE PENELITIAN}

Penelitian ini dilakukan di SDN No 89 Sipatana. Penelitian ini dilakukan bulan Maret sampai dengan bulan Juni 2019.

Subjek penelitian adalah siswa kelas VI yang berjumlah 13 orang, terdiri 8 orang laki-laki dan 5 orang perempuan. Para siswa berasal dari latar belakang keluarga yang berbeda dan mempunyai tingkat kemampuan yang berbeda pula.

Adapun prosedur penelitian terdiri dari tahap perencanaan, tahap pelaksanaan, tahap pemantauan dan evaluasi serta tahap analisis dan refleksi. Data dalam penelitian tindakan kelas ini digunakan beberapa instrumen pengumpul data yang terdiri dari observasi, wawancara, tes dan dokumentasi. Analisis data dilaksanakan secara kualitatif 
dan kuantitatif pada setiap akhir siklus pembelajaran.Data yang dianalisis meliputi observasi kegiatan guru dan aktivitas siswa serta data hasil belajar siswa.

\section{HASIL PENELITIAN DAN PEMBAHASAN}

Hasil pengamatan pada kegiatan yang dilakukan oleh guru pada siklus II menunjukkan bahwa telah memenuhi syarat prosentase ketercapaian kriteria persiapan kegiatan yang dilaksanakan dari 24 APKG pencapaian sebesar 79\% atau sekitar 19 item yang dapat dipenuhi oleh guru sebelum melaksanakan Siklus II, sementara masih terdapat $21 \%$ atau 5 item dari kriteria APKG yang cenderung diabaikan oleh guru dalam proses pembelajaran. Sehingga hasil pengamatan aktivitas guru dalam penerapan metode simulasi telah berpengaruh pada pemahaman siswa materi perjuangan melawan penjajah

Meningkatnya penerapan aspek yang berhubungan dengan metode simulasi pada saat proses pembelajaran berlangsung disetiap tindakan berimbas pada peningkatan hasil evaluasi pemahaman siswa materi perjuangan melawan penjajah. Adapun rekapitulasi hasil evaluasi pemahaman siswa materi perjuangan melawan penjajah yang dibawakan guru selama dua kali tindakan.

Setiap aspek yang diujikan dalam evaluasi pemahaman siswa materi perjuangan melawan penjajah yang disampaikan guru mengalami peningkatan disetiap tindakan yang dilaksanakan. Mulai dari observasi awal, siklus I dan siklus II. Adapun hasilnya pada siklus II adalah bahwa pada aspek Kemampuan Mendeskripsikan terdapat 11 atau 84.62\% siswa berada pada kategori paham, 2 atau $15.2 \%$ pada kategori kurang paham, 10 atau $76.92 \%$ berada pada kategori tidak paham. Untuk aspek Kemampuan Merespon Belajar terdapat 11 atau $84.62 \%$ berada pada kategori paham, 3 atau $23.08 \%$ berada pada kategori kurang paham, $0 \%$ berada pada kategori tidak paham. Sedangkan aspek Kemampuan kerjasama kelompok terdapat 11 atau $84.62 \%$ berada pada kategori paham, 1 atau $7.69 \%$ berada pada kategori kurang paham, 1 atau $7.69 \%$ berada pada kategori tidak paham.

Tabel 1: Rangkuman Kegiatan Pembelajaran Siswa materi perjuangan melawan penjajah

\begin{tabular}{|c|c|c|c|c|c|c|c|}
\hline \multirow{3}{*}{\multicolumn{2}{|c|}{$\begin{array}{l}\text { Pengamatan } \\
\text { Observasi } \\
\text { awal }\end{array}$}} & \multicolumn{6}{|c|}{ INDIKATOR PENILAIAN } \\
\hline & & \multicolumn{2}{|c|}{ Partisipasi Siswa } & \multicolumn{2}{|c|}{ Keberanian Siswa } & \multicolumn{2}{|c|}{ Kerjasama } \\
\hline & & $\mathbf{T}$ & TT & $\mathbf{T}$ & TT & $\mathbf{T}$ & TT \\
\hline \multirow{2}{*}{$\begin{array}{l}\text { Siklus } \\
1\end{array}$} & Jlh & 7 & $\mathbf{0}$ & 8 & 1 & 8 & 1 \\
\hline & NRR & 53,85 & 46,15 & 61,54 & 7,69 & 61,54 & 7,69 \\
\hline \multirow{2}{*}{$\begin{array}{l}\text { Siklus } \\
2\end{array}$} & Jlh & 11 & - & 10 & - & 11 & 1 \\
\hline & NRR & 84,62 & 15,48 & 76,92 & 23,08 & 92,31 & 7,69 \\
\hline
\end{tabular}

Berdasarkan tabel tersebut dapat diperoleh informasi bahwa setiap kali tindakan dilakukan selalu mengalami peningkatan yang signifikan terbukti indikator kinerja yang ditetapkan berhasil yaitu jika sebelumnya jumlah siswa yang paham materi perjuangan melawan penjajah pada siklus 1 hanya sebanyak 9 siswa $(69.23 \%)$ meningkat pada siklus 2 menjadi 12 orang siswa $(92.3 \%)$ siswa. Sedangkan 1 atau (7.69\%) siswa merupakan jumlah siswa yang kurang paham dan akan diperbaiki melalui proses remedial. 
Hasil tersebut memberikan gambaran perbedaan ketika guru kelas menggunakan proses pembelajaran yang konvensional tanpa memahami bagaimana kondisi siswa dalam mengikuti proses pembelajaran dengan pemilihan dan penerapan metode simulasi secara tepat dengan langkah-langkah yang sesuai disetiap tindakan memperoleh hasil pembelajaran yang maksimal. Oleh karenanya peneliti telah yakin bahwa dengan menggunakan Metode Simulasi dalam pelajaran IPS maka pemahaman belajar siswa Kelas VI SDN No 89 Sipatana akan meningkat dapat diterima.

\section{KESIMPULAN}

Berdasarkan penyajian data dan pembahasan dalam penelitian ini dapat ditarik kesimpulan sebagai berikut:

Hasil penelitian menunjukkan setiap kali tindakan dilakukan selalu mengalami peningkatan yang signifikan terbukti indikator kinerja yang ditetapkan berhasil yaitu jika sebelumnya jumlah siswa yang paham materi perjuangan melawan penjajah pada siklus 1 hanya sebanyak 9 siswa (69.23\%) meningkat pada siklus 2 menjadi 12 orang siswa (92.3\%) siswa. Sedangkan 1 atau (7.69\%) siswa merupakan jumlah siswa yang kurang paham dan akan diperbaiki melalui proses remedial.

Hasil tersebut memberikan gambaran perbedaan ketika guru kelas menggunakan proses pembelajaran yang konvensional tanpa memahami bagaimana kondisi siswa dalam mengikuti proses pembelajaran dengan pemilihan dan penerapan metode simulasi secara tepat dengan langkah-langkah yang sesuai disetiap tindakan memperoleh hasil pembelajaran yang maksimal. Oleh karenanya peneliti telah yakin bahwa dengan menggunakan Metode Simulasi dalam pelajaran IPS maka pemahaman belajar siswa Kelas VI SDN No 89 Sipatana akan meningkat dapat diterima.

\section{SARAN}

Dalam kesempatan ini peneliti sekaligus sebagai penulis akan memberikan saran yang kiranya dapat dijadikan pegangan dalam menjalankan tugas sebagai seorang pendidik yaitu :

1. Hendaknya guru lebih aktif dalam menggunakan metode simulasi pada mata pelajaran IPS terutama pelajaran lainnya agar siswa tidak menjadi bosan dalam belajar.

2. Sebagai tindak lanjut penerapan, pada saat proses pembelajaran diharapkan kepada guru untuk lebih mengawasi dan mengontrol siswa serta membimbing siswa khususnya dalam pembelajaran.

\section{DAFTAR PUSTAKA}

Abu Ahmadi (et, al), 2005. Strategi Belajar Mengajar, Bandung: Pustaka setia Anitah, Sri, W, dkk. 2007. Strategi Pembelajaran di SD. Jakarta: Universitas Terbuka. Aunurrahman, 2009. Belajar dan Pembelajaran, Bandung: Alfabeta

Azwar, Saifuddin. 2005. Sikap Manusia: Teori dan Pengukurannya. Yogyakarta: Pustaka Pelajar.

Djamarah Bahri Syaiful, Zain Aswan, 2006. Strategi Belajar Mengajar, Jakarta : Rineka Cipta

Hamalik Oemar, 2011. Proses Belajar Mengajar, Jakarta : Bumi Aksara 
Hamzah B. Uno dan Satria M.A. Koni, 2009. Penelitian Tindakan Kelas, Bandung: MQS Publishing

Mufarrokah, Anissatul. 2009. Strategi Belajar Mengajar, Yogyakarta: Teras,

Nana Sudjana, 2004. Penilaian Hasil Proses Belajar Mengajar, Bandung: Remaja Rosdakarya

Riyanto Yatim, 2010. Paradigma Baru Pembelajaran, Jakarta : Kencana Prenada Media Group

Sardiman, A.M., 2007. Interaksi dan Motivasi Belajar Mengajar, (Jakarta: Raja Grafindo Persada,

Sardiman, A.M., 2007. Interaksi dan Motivasi Belajar Mengajar, (Jakarta: Raja Grafindo Persada,

Slameto, 2011. Belajar dan Faktor-Faktor Yang Mempengaruhinya. Rineka Cipta Jakarta.

Syaefudin, Udin., Syamsuddin, Abin. 2005. Perencanaan Pendidikan Pendekatan Komprehensif. Bandung: PT Remaja Rosdakarya.

Trianto, 2010. Mengembangkan Model Pembelajaran Tematik. Jakarta: Prestasi Pustakaraya

Uzer, Moh. Usman, 2007. Menjadi Guru Profesional, Jakarta: Rosda Karya

Winataputra, Udin, S. 2011. Model-model Pembelajaran Inovatif. Jakarta Pusat: Direktorat Jenderal Pendidikan Tinggi Departemen Pendidikan Nasional.

AngketatauKuesionerhttp//hamimnurham.wordpress.com/2012/05/20/pe ngertianwawancara dan angket/

Buku paket PKN Erlangga kelas V hal.8-20 Kumpulan soal-soal latihan PKNkelas V semester gasal hal.13-18.

Depdiknas, 2008. Peraturan Menteri Pendidikan Nasional. Jakarta. Depdiknas Dr.H.Samino,MM.2011.Layanan Bimbingan Belajar. Surakarata: FKIP -

UMS, halaman 30.

Drs.Joko Suwandi, M.Pd. 2011. Penelitian Tindakan Kelas (Classroom Action Research). PSKGJ- FKIP UMS. Surakarta : Qinant hal. 37

Dra. Sri Hartini, SH. M.PD.2011. Evaluasi Pembelajaran. PSKGJ- FKIPUMS. Surakarta : Qinant halaman 15

E.Mayasa ( dikutip dari Makalah Strategi Belajar Mengajar yang Efektif dan Efisien di Sekolah Dasar yang disusun oleh Nining Indrastuti, Trimakarti dan Krisnawati ).

Hidayat, Nur. 2011. Media Pembelajaran dan ICT. Surakarta. QinantHipni, Rohman. 2009, Definisi / pengertian strategi pembelajaran http://hipni.blogspot.com/2011/09/definisi-pengertian-strategi.html 
pengertian metode simulasi: http://alief-hamsa.blogspot.com/2009/08/metode simulasi.html

Pengertian motivasi: http://www.duniapsikologi.com./pengertian-motivasi/

Rubiyanto, R.2009. Metode Penelitian Pendidikan . Surakarta: FKIP UMSSutan Syahrir Zabda, Kajian Kurikulum PKN. FKIP UMS

Tujuan simulasi: http://zanuarinirental.blogspot.com/2011/09/penggunaanmetode-simulasi-pada.html

Uno, Hamzah. 2007. Teori Motivasi dan Pengukuran nya. Jakarta Bumi Aksara

Zaini, Hisyamdkk.2007,Strategi Pembelajaran Aktif .Yogyakarta,: CTS 